\title{
Antony Flew'ün Ateizmden Tanrı İnancına Yolculuğunda Kanıtların Rolü: Eleştirel Bir Yaklaşım
}

Mehmet Şükrü ÖZKAN *

Öz

$\mathrm{Bu}$ çalışma Antony Flew'ün ateizmden Tanrı inancına dönüş serüvenini incelemektedir. Bu açıdan bakıldığında onun entelektüel hayatını iki döneme ayırmak mümkündür. Ateist olarak geçirdiği ilk dönem ve Tanrı inancına sahip olduğu ikinci dönem. Flew ateist olduğu dönemde belli argümanlardan yola çıkarak Tanrı́nın varlığının imkânsızlığını savunmuştur. Tanrı inancına sahip olduğu dönemde ise bu argümanlarda işaret edilen problemlere cevap bulduğunu ve yeni kanıtlarla birlikte Tanrı'nın varlığını kabul ettiğini ifade etmiştir. Dolayısıyla bu çalışmanın temel gayesi bu dönüşümdeki gerekçelerin tutarlı olup olmadığını sorgulamak, varılan noktada Flew'ün sahip olduğu Tanrı inancının dini açıdan yansımalarını tartışmaktır.

Anahtar Kelimeler: Ateizm, Bilim, İman, Kanıtlama, Tanrı.

\section{The Role of Evidences in Pilgrimage of Antony Flew from Atheism to Belief in God: A Critical Approach}

\begin{abstract}
This study examines Antony Flew's pilgrimage in transforming from atheism to belief in God. From this perspective, it is possible to divide his intellectual life into two periods as the first period in which he spent his life as an atheist and the second period in which he had the belief in God. Setting off from certain arguments, Flew argued the impossibility of the existence of God in the period in which he was an atheist. In the period that he had belief in God, he argued that he found the answer to the problems pointed out in these arguments and with new evidence, he accepted the existence of God. Therefore, the basic objective of this study is to question whether the reasons in this transformation are consistent with and to discuss the reflection of Flew's belief in God at the conclusion in terms of religion.
\end{abstract}

Keywords: Atheism, Science, Faith, Proving, God.

Dr. Öğretim Üyesi, Şırnak Üniversitesi İlahiyat Fakültesi, msozkan1250@gmail.com 


\section{GIIRIS}

Antony Flew, Tanrı’nın varlığı ve yokluğu tartışması kapsamında son dönem ateizmteizm karşıtlığında önemli bir konumdadır. Dolayısıyla özellikle din felsefesi alanındaki çalışmaların ilgi odağı olmuştur. Bunun sebebi Flew’ün Tanrı́nın var olup olmadığı noktasındaki tutumunun iki döneme ayrılmasıdır. Bu da ateizmi savunma ve eleştirme dönemleri olarak ifade edilebilir. Bu iki dönem karşılaştırıldığında, ilk dönemin kaynak, süre, tartışma vb. unsurlarıyla birlikte ikinci dönemden çok daha teferruatlı olduğu gözlenmektedir. Bundan dolayı Flew'ün ateizm eleștirisini kapsayan ikinci dönemindeki düşüncelerinin çok net temellendirilmediğini ileri sürebiliriz. Ülkemizde "Yanılmışım Tanrı Varmış" (Flew, 2004) başlı̆̆ıyla tercüme edilen kitabı, bu dönemle ilgili en kapsamlı çalışmasıdır. Özetle biz bu dönemin değerlendirilmesinde daha çok bu kitabı kaynak almak durumunda kalacağız.

Flew, ömrünün altmış yılı aşkın süresini ateist olarak sürdürmüş, bu süre zarfında her ateistin sahip olduğu "Tanrı yoktur", "Tanrı ile ilgili inanç, bekâr kocalar ve yuvarlak kareler ifadeleri ile aynı anlamdadır", "evrenin bir başlangıcı olmadığı gibi sonu da yoktur", "yaşayan organizmalar, cansız organizmalardan uzun bir dönem sonunda evrim geçirerek meydana gelmiştir” gibi belli önermeleri kabul etmiştir. Ayrıca bu önermelere bağlı olarak 2004'e kadar Thomas B. Warren, William L. Craig, R. Swinburne, Alvin Plantinga, G. Habermas vb. birçok teist filozofla münazaralarda bulunmuş, Tanrı’nın var olmadığını, evrenin bir başlangıcı olmadığını ve ilk sebep kanıtının geçersizliğini, Tanrı’nın var olması durumunda sürekli iyiyi yapan özgür varlıklar yaratabileceğini, evrendeki karmaşık düzenin Tanrı’nın varlığıyla açıklanamayacağını ve evrendeki karmaşık varlıkların bilinçsiz fiziksel kuvvetlerin ürünü olduğunu vb. önermeleri savunmuştur (Flew, 2004: 73-79). ${ }^{2}$ Ateist fikir, inanç ve ifadelerin sahibi olan Flew, tam bir dönüş ile 2004'te New York'da gerçekleşen bir sempozyumda Tanrı’nın varlığını kabul ettiğini ilan etmiştir. Bu sempozyumda kendisine hayatın kaynağına dair son çalışmaların yaratıcı bir zekâya işaret edip etmediği sorulduğunda olumlu cevap vermiştir (Flew, 2004: 79). ${ }^{3}$

Flew için önemli olan kanıtın kendisini götürdüğü yere gitmektir. Bu açıdan bakacak olursak Flew'ün ateizm düşüncesinden Tanrı inancına yolculuğunu bu ilke çerçevesinde düşündüğümüzde pek de şaşılacak bir olguyla karşılaşmamış oluruz. Aynı şekilde Flew, Hume'un felsefi düşüncesi ve özgür irade konularında önceki fikirlerinin tam tersi

2 Gary Habermas, kendisiyle 2003 öncesindeki görüşmelerinde Tanrı düşüncesine, vahye, mucizelere ve ölüm sonrası hayata açık olduğu noktasında Flew’ün görüş belirttiğini fakat 2003 yılında bazı soru işaretlerinden dolayı ateist olarak kalmaya kararlı olduğunu belirttiğini ifade etmektedir. 2004 yılına gelindiğinde kendisinin Tanrıya inandığını fakat vahiy ve diğer konularda çekimser olduğunu hatta kanıta göre hareket edeceğini bildirdiğini söylemektedir (Habermas, 2007: 431-432).

3 Son dönemde ateizmden Tanrı inancına dönüş olgusu her ne kadar Flew ile tartışma konusu olsa da uzunca bir süre ateist olarak kaldıktan sonra Tanrı inancına sahip olduğunu belirten farklı düşünürler de vardır. Bunlardan biri de Fancis S. Collins'tir. Onun Tanrı inancına dönüş gerekçelerini ve kabul ettiği kanıtlar için bkz (Collins, 2007; Collins, 2010). 
fikirlere sahip olduğunu söyleyerek, düşüncesinde meydana gelen değişimlere örnek vermektedir (Flew, 2004: 65-69). Yani Flew, kendi iddiasına göre kendi koyduğu ilkeye sadık kalarak, sadece inanç konusunda değil birçok felsefi meselede düşünce değişimi yaşamıştır. Yıllarca süren münazaralardan sonra Tanrı'yı kabul etmesinin tamamen doğal teoloji yoluyla olduğunu ifade ederek, Tanrı’yı keşfinin hiçbir doğaüstü fenomen ya da tecrübeyle gerçekleşmediğini yani bu yolculuğun her hangi bir dini inançla ya da imanla değil akılla olduğunu vurgulamıştır (Flew, 2004: 93). ${ }^{4}$

Bizim bu çalışmada sorgulayacağımız temel meselelerden biri Flew'ün gerçekten "kanıtların götürdüğü yere git" olarak nitelenen ilkeye sadık kalarak hareket edip etmediğidir. Flew, bu ilkeyi ele alarak farklı iki dönem yaşamış ve son bilimsel gelişmeler sonucunda kanıtların Tanrı́nın varlığına işaret ettiği sonucuna varmıştır. Bu noktada sorulacak en temel soru, kanıtların gerçekten ve kesin olarak Tanrı́nın varlığına işaret edip etmediği ve Flew’ün inanmasında tüm rolün kanıtlarda olup olmadığıdır. Dolayısıyla onun ateizmden Tanrı inancına dönüşünün ne kadar rasyonel olduğu tartışmaya açılmak zorundadır. Ayrıca ateist ve deist dönemdeki argümanları karşılaştırdığında, Flew'ün kendisinin ateist olmasına neden olan argümanlarının ne kadarına cevap bulduğu ve hangi problemi ne ölçüde çözüme kavuşturduğu onun Tanrı inancına sahip olması bakımından irdelenen diğer bir husustur. Kısaca onun ateist dönemdeki argümanlarına Tanrı inancına sahip olduğu dönemdeki cevapları ve bulduğu çözümlerin ikna edici olup olmadığı bu çalışmanın odak noktasıdır. Bu nedenle ilk dönemi işlerken Flew’ün öne sürdügü tezlerin değerlendirmesi yapılmamış, sadece ilk ve ikinci dönem arasındaki düşüncelerin tutarlı olup olmadığ tartışılmıştır.

\section{1. İLK DÖNEM: ATEIZZMINIIN TEMELLERİ}

Genel olarak ateistlerin teistlere yönelttiği itirazları; kanıtlara yönelik eleştiriler, sosyolojik ve psikolojik tabanlı düşünceler, kötülük problemi ve teistik iddiaların anlamsızlı̆̆ı üzerine inşa edilmiş argümanlar ve ispat sorumluluğunun teistlerde olduğu iddiası gibi gerekçelerden yola çıkarak temellendirilir. Mesela Ernest Nagel, ateistlerin teistlere yönelttiği epistemolojik itirazları şu şekilde sıralar: 1. Teistik kanıtlar anlamlıdır fakat bu kanıtlara inanmayı gerektirecek pozitif kanıtlar olmamakla birlikte, negatif kanıtlar kolayca çürütülebilecek niteliktedir. 2. Teistik tezler hiçbir epistemolojik değeri olmadığ1 ve sadece beşeri arzuların yansıması olduğu için anlamsızdır (Nagel, 1997: 6). Flew’ün ateizminin temelinde de üç gerekçe bulunmaktadır. Bunlardan ilki kötülük meselesinde belirtilen sorunlara teistlerin mantıklı bir cevap verememesi, ikincisi teistlerin Tanrı'nın varlığı lehinde kullandıkları argümanların ikna edicilikten uzak olması, üçüncüsü ise Tanrı ile ilgili kullanılan önermelerin "Yanlışlama İlkesi” ile ters düşmesidir. İspat sorumluluğunun teistlerde olduğu görüşü de kendisince israrla vurgulanmaktadır.

4 Ateist meydan okumaya karşı üç epistemolojik tutum vardır. Bunlar; fideizm, reformist epistemoloji gibi doğal teolojidir. Doğal teolojide diğer iki tutumdan farklı olarak Tanrının varlığı delilci yöntem kullanılarak temellendirilmeye çalışılır. Doğal teolojide vahiy veya her hangi bir başka otoriteye başvurmaksızın doğal yollardan Tanrının bilgisine ulaşmak amaçlanmaktadır. Ayrıntılı bilgi için bkz (Mehdiyev, 2008). 
Flew, ateizmi savunan düşüncelerini “Theology and Falsification"da (Flew, 1955) ifade ettikten sonra "God and Philosophy”de (Flew, 2005) bu düşünceleri geliştirmiştir. “Theology and Falsification" dindarların öne sürdükleri iddiaları açıllama amacı güdüyorken, "God and Philosophy" ise ateizmin sistematik iddialarını içeren bir çalışmadır. Flew, bu çalışmada Tanrı kavramının tutarlılığı, uygulanabilirliği ve akla yatkınlığı meselelerini tartışmakla birlikte doğal teoloji ve ilahi vahiy konularını ele almıştır. Düzen ve amaçtan, kozmolojik ve ahlaki iddialardan yola çıkarak veya belirli bir dini deneyim yoluyla Tanrı’nın varlığının savunulamayacağı Flew’ün bu kitaptaki temel argümanıdır.

\subsection{Tanrı Hakkında Konuşmanın İmkansızlı̆̆ı}

Felsefi düşünceye bakıldığında düşünürler ya Tanrı hakkındaki kelime ve kavramların anlamları ya da inançların tahlil ve değerlendirilmesi için din diline ilgi göstermişlerdir. Ateist olsun olmasın birçok filozof Tanrı hakkında konuşulup konuşulamayacağı veya hangi surette konuşmanın anlamlı olacağı meselesini tartışmıştır. Bu düşünürlerden biri olan Flew, ateizmi savunduğu dönemde Tanrı hakkında konuşmak üzerine düşüncelerini mantıksal pozitivizme dayandırmaktadır. Buna göre bir önermenin olgusal konular ya da gerçeklikler hakkında bilgi sunması için önermenin sentetik ve olgusal yoldan doğrulanabilir olması gerekmektedir. Mesela teolojik önermeler Tanrı hakkında bilgi iddiasında oldukları için olgusal açıdan doğrulanmaları gerekir. Fakat mantıksal pozitivistlere göre bu tarz önermeler olgusal açıdan doğrulanamamakla birlikte hiçbir anlam ifade etmemektedirler (Evans, 2010: 28).

Flew, bazı kavramların ne somut ne de somut olmayan şeylere işaret ettiğini, bu sebeple onların, sadece onları kullananların tanımladıkları işleve göre anlamlandırılması sonucu türediğini ileri sürmektedir. Yani bu kavramlar, işaret ettiği her hangi bir nesne ya da tür olmaksızın, sadece kullanımlarının uygun veya uygun olmayan durumlarına göre anlam kazanmaktadırlar. Tanrı kavramının bu şekilde değerlendirilmesi gerektiğini savunan Flew, Kutsal Kitap veya başka bir yerde bu kavramın kişisel bir varlığa işaret ettiğini kanıtlayacak her hangi bir somut veriye sahip olunmadığını öne sürmektedir. Buna göre Tanrı kavramının gerçek bir nesneye uygulanması imkânsızdır. Çünkü kendisi hakkında konuşulamayan manevi varlık olarak nitelendirilen bir şey kişisel varlığı tanımlamak için kullanılamaz. Mesela Tanrı hakkında konuşma ihtiyacı hisseden Hıristiyanlar onun manevi alandaki ifade edilemezliği sorununu, İsa üzerinden çözmeye çalışmaktadırlar. Hasılı Tanrı hakkında konuşmayı İsa hakkında konuşmaya dönüştürmüşlerdir. Fakat Tanrı'yı kendinde varlık olarak tanımlayıp soyutlamak, onun kişisel bir varlık olarak nitelendirilmesini olanaksızlaştırmaktadır. (Flew, 2005: 32-34). ${ }^{5}$

5 Flew'ün bu düşüncelerine karşı Thomas Aquinas'ın benzer anlamlılık teorisi zikredilebilir. Bu teoriye göre bir kelime hem yaratılmış bir varlığa hem de Tanrı’ya izafe edildiğinde ne tam anlamıyla aynı ne de farklı anlamda kullanılır. Mesela adil kavramı insan ve Tanrı hakkında kullanıldığında her ne kadar insan ile Tanrı'nın adaleti aynı olmasa da ilahi adaletle insani adaletin arasındaki bağlantı sebebiyle bu kavramın iki varlığa da benzer anlamıyla yüklem yapılabileceği söylenebilir. (Aquinas, 1975: $28 \mathrm{vd).}$ 
Bu düşünceler paralelinde Flew'ün öncelikli hedefinin, Tanrı’nın varlığı ile ilgili kanıttan yoksun olup olmamak değil, Tanrı́nın var olduğu iddiasının ne anlama geldiğini göstermek olduğu ileri sürülebilir. Dolayısıyla temel düşüncesi Tanrı'nın var olduğu ve insanları sevdiği gibi iddiaların bilişsel açıdan anlamsız olduğudur. Çıkış noktası ise öne sürülen bu tarz iddiaların bazı şeyleri dışarıda bıraktığı düşüncesidir. Mesela dünyanın yuvarlak olduğu iddiası onun düz olma ihtimalini dışlamaktadır. Fakat ona göre teistlerin öne sürdüğü iddialar böyle değildir. Çünkü onlar iddialarının aleyhine hiçbir şeyi kabul etmemektedirler. Aksine her durumu öne sürdükleri iddianın lehine çevirmektedirler. Tanrı’nın insanları sevdiği iddiası bu şekilde değerlendirilebilir. Acının ya da sstırabın varlığı, farklı nitelendirmelerle birlikte onun varlığıyla ve sevgisiyle bağdaştırılmaktadır. Burada Flew, dini inanç sahiplerinin kabul ettikleri ve inanılması için öne sürdükleri iddiaların, olumsuz olgular bulunsa dahi iddialarının aksini öne sürecek herhangi bir pozisyona müsaade etmediğini düşünmektedir. Yani teist iddialar her hangi bir iddiayı dışarıda bırakmamakta ve yanlışlamamaktadır (Flew, 1955: 97-99). Teolojik dilin sınırları vardır ve günlük dil pervasızca bu dil yerine kullanılmaktadır. Mesela "Tanrı insanları sever" cümlesini kullandığında Tanrı ve sevmek kavramlarının anlamsal sınırlarını belirleyemediğimiz gibi bu anlamların günlük dilde olduğu gibi kullanılması Flew’a göre Tanrı ile bu dünya arasındaki ontolojik farkı ortadan kaldırdığı gibi iki önermenin eşdeğer kabul edilmesi tutarsızlık içerir. Çünkü insani alanda tecrübe konusu olabilecek şeylerin Tanrı söz konusu olduğunda anlamsızlaştığı görülmektedir (Flew, 1969: 77-79).

Flew’ün bu düşünceleri farklı din dili teorisine sahip düşünürler tarafından eleştirilmiştir. R. M. Hare, dini ifadelerin açıklamada bulunmak şeklinde değil, genel bir tutum olarak bir şeyin ifade edilişi anlamında "blik" olarak kabul edilmesini önermiştir. Hare’e göre blik, deneyimimizin doğrulanamayan ve yanlışlanamayan bir yorumlamasından ibaretti. Çünkü blikler yanlışlanamaz kanaatlerdir. Onlar birer önerme olmasalar da güçlü blikler davranışlara yön verdiği için doğru bliklere sahip olmak gerekir (Hare, 1955: 99-100). Flew’ün düşüncelerine yöneltilen diğer eleştiri Basil Mitchell'den gelmiştir. Mitchell'e göre teolojik ifadelerde öne sürülen iddialara karşı gelen iddialar vardır ve bunu teologlar kabul etmektedir. Mesela acı çekmelerin Tanrı́nın varlığına ve bizi sevdiğine karşı kanıt olarak kullanılması mümkündür. Fakat inananlar Tanrı’nın varlığına ve sevgisine dair yeterli kanıta sahip olduklarını düşündüğü için bu ifadeler nihai yargı anlamında ele alınmamalıdır. Böylece yeterli derecede gösterilemese de Tanrı'nın varlığına ve iyiliğine inanıldığı için, onun eylemlerinin iyi bir nedeni olduğu düşünülebilir. Neticede dini inançlar aslında bir önermedir ve prensipte de olsa yanlışlanabilme özelliğine sahiptir. $\mathrm{Bu}$ özelliğe sahip inançların pratikte nasıl yanlışlanacağı ise net değildir (Mitchell, 1955: 103-105).

Stephan Evens’a göre teolojik önermelerin hiçbir şeyle açık olarak uyumlu olmadığı ve metafiziksel bir önermenin mukabiliyle yanlışlanabileceği söylenebilir. Mesela "Tanrı vardır” önermesi Tanrı’nın var olmayışıyla yanlışlanabilir. Her ne kadar Flew yanlıșlamanın olgusal düzeyde olacağını ileri sürecek olsa da, bu savunma Flew'un yorumunun dini inançlara öldürücü darbe vurmasını engeller (Evans, 2010: 259). Raeburne Heimbeck, “Teoloji ve Yanlışlama”nın üç temel hata yaptığını öne sürmektedir. Bu hatalardan ilkinde, 
her hangi bir cümlenin anlamının, iddia ettiği deneysel imalarla aynı olduğu, ikincisinde bir inanca karşı olmanın onla uyuşmamak anlamına geldiği, üçüncüsünde ise Tanrı ile ilgili açıklamaların yanlışlanamaz olduğunu iddia edilmektedir (Flew, 2004: 55-56).

Swinburne, Flew'ün yanlışlama ilkesinin genişletilmesi halinde bilimsel dilin de bu ilke çerçevesinde anlamsız olduğunun söylenebileceğini iddia etmektedir. Şöyle ki yanlışlama ilkesinin temelinde önermelerin reddedilebilme niteliği aranmaktadır. Swinburne, reddedilebilirlik durumunun bilimsel iddialara uygulanması sonucunda, bu iddiaların belli bir noktaya kadar reddedilebildiği ve daha ileri gidilemediğinin görüleceğini belirtmektedir. Yani en güvenilir bilgi olarak kabul edilen bilimsel bilginin bile belli ölçüde yanlışlanabilirlik ilkesine uygun olduğu Swinburne’ün dikkat çektiği husustur (Swinburne, 1977: 88).

Neticede Flew, Tanrı var mıdır? sorusundan ziyade hangi Tanrı tasavvuru doğru kabul edilmelidir? ya da Tanrı gerçekte neye tekabül etmektedir? sorularının irdelenmesi gerektiğini ileri sürmektedir. Çünkü ona göre bir Tanrı’nın bütün ayrıntılarıyla belirlenmiş bir şekilde tanımlanmasının açıklaması yapılmadan onun var olup olmadığı hakkında tartışmaya girişmek anlamsızdır (Flew, 2005: 31). Böyle bir varlığın evrenden nasıl ayrılabilir şekilde tanımlanacağı onun için hiç de açık olmayan bir şeydir. Bu varlığın tek ve değişmez olduğu, zaman içinde ya da dışında etkin bir varlık olduğu iddiasına hangi anlamın yüklenebileceği onun için belirsizliğini korumaktadır. Ona göre gerçekten tutarlı ve uygun bir kavramla açıklanamadığı sürece böyle bir varlı̆̆ın var olup olmadığı konusunda her hangi bir iddiada bulunulmaması gerekmektedir. Yani Tanrı'nın nasıl tanımlanacağı belirlenene kadar, belirli bir Tanrı tipine inanma nedenleri tartışılamaz. Çünkü Flew’a göre "her yerde bulunan bedensiz bir varlık"ın tanımlanabilmesi oldukça meşakkatli bir iştir. Bedeni olmayan, her zaman ve her yerde hazır bulunan, her şeyin yaratıcı ve devam ettirici sebebi, mutlak kudret ve iyiliğe sahip varlık olarak Tanrı tanımlaması Flew’ün kabul edebileceği bir şey değildir (Flew, 2005: 28-29).

İster doğrulama ister yanlışlama ilkesinden hareket edilsin, mantıksal pozitivist düşüncenin objektif olduğunu söylemek imkânsızdır. Aslına bakarsak ulaşttğımız bütün bilgilerin kesin doğrulanmış bilgiler olduğunu söyleyemeyeceğimiz gibi hakkında bilgi sahibi olduğumuz bütün objelerin de nesnel, gözlemlenebilir şeyler olduğunu söyleyemeyiz. Bundan dolayı günlük konuşma dilinde mutlak kesinlik kazanmasa da ihtimal içeren önermelerden yola çıkarak günlük yaşantımızı devam ettirdiğimiz aşikârdır. Dolayısıyla Tanrı hakkında öne sürülen önermelerin doğrulanamayacağı ya da yanlışlanamayacağını öne süren mantıksal pozitivistlerin hayatlarının hiçbir alanında, kendi ortaya koydukları ilkelerin süzgecinden geçmemiş önermelere yer vermediklerini göstermek durumundadırlar. (Çetin, 2002: 98).

\subsection{Kanıtların Eleştirisi}

Düşünce tarihinin başlangıcından günümüze kadar Tanrı’nın varlığını kanıtladığını öne süren birçok düşünür ve bu düşünürlerin öne sürdüğü farklı kanıtlama örnekleri mevcuttur. Tümevarımsal ya da tümdengelimsel şekillerde gerçekleşen kanıtlama girişimlerine 
karşı, bu kanıtlama girişimlerinin kesin ispatlama olmadığı sadece kanıtlama girişimi olarak nitelendirilebileceği, bundan ötürü bu örneklerin hipotez anlamında argüman olarak kabul edilebileceği ifade edilmiştir. ${ }^{6}$ Kanıtın götürdüğü yere git ilkesince hareket eden Flew, Tanrı’nın varlığını kanıtlamaya yönelik kanıtların eleştirisini daha çok "God and Philosophy"' adlı eserinde temellendirmektedir. Yukarıda Görüldügüü üzere Flew’a göre "Tanrı vardır” ifadesi kesin bir hüküm içermemekteydi. Şayet öyle olsaydı Tanrı’yı kanıtlamaya gerek kalmaz ve bu kadar çaba harcanmazdı. Dolayısıyla bu kanıtların hiçbir faydası yoktur (Flew, 2005: 134). Fakat o yine de öne sürülen kanıtların eleştirisini yapma zorunluluğu hissetmiştir.

Ontolojik argümanın geçerliliğini kabul etmeyen Flew, bu argümanda kavramdan gerçek varlığa doğru hatalı bir sonuca gitme girişimi olduğunu ileri sürmüştür. Ona göre mükemmel varlık fikrinden Tanrı'nın gerçekte var olduğu düşüncesine ulaşmak kolay değildir. Çünkü bu argümanın içinde böyle bir geçişi sağlayacak her hangi bir adım mevcut değildir. Gerçek varlık, gerçekte sahip olunan bir niteliğin durumudur. Gerçek varlığı zihnin tanımlayıcı niteliklerden birisi gibi görmek ve kavramdan yola çıkarak bir şeyin gerçek varlığına ulaşma çabası mantıksız bir uğraştır. Bundan dolayı Flew, kavramlar ve gerçek varlıklar arasındaki farkın anlaşılması durumunda ontolojik argümanın saçmalığına düşülmeyeceğini vurgulamaktadır (Flew, 2005: 79-81). Flew’ün belirttiği gibi ontolojik kanıtta varlık, Tanrı kavramından yola çıkılarak, her şeye gücü yeten, her şeyi bilen vs. niteliklerle bir Tanrı’ya özne yapılmakta ve bu Tanrı'nın gerçekte var olduğu kabul edilmektedir. Bir bakıma Tanrı hakkında aklın ilkelerinden hareketle ve kavramlar aracılığıyla hüküm verilmektedir. Oysa insan aklının, numen alanını ve Tanrı́nın varlığını, kavramından çıkarması mümkün değildir. Çünkü zihindeki varlığın, varlığı gibi yokluğunu da düşünmek çelişki içermemektedir. Modern dönemde bu argümanı revize etmeye çalışan N. Malcolm ve R. Swinburne gibi düşünürlerin argümanları da varlığın yüklem oluşu fikrini hedef alan eleştirilerden kurtulamazlar (Çınar, 2008: 93-99).

Flew, diğerlerine nazaran kendi içinde çeşitli iddialar barındıran kozmolojik kanıtın da

6 Tanrı’nın varlığını kanıtlama girişimlerine karşı sadece ateist değil fideist kanattan da eleştiriler gelmiştir. Mesela Tanrı’yı kanıtlama girişimlerinin faydasız ve gereksiz olduğu görüşlerini fideist temelde gerçekleştiren Kierkegaard'in düşünceleri için bkz. (Kierkegaard, 1962: 31-33).

7 Flew, God and Philosophy adlı kitabını 2004'de Philosophy Now'a yazdığı bir mektupta tarihi bir kalıntı, demode olmuş ve şu anki tartışmalara bir fayda sağlayamayacak tarihi bir doküman olarak gördüğünü dile getirmiştir. (Flew ve Habermas, 2004: 202). Bu kitapta ele alınan konular hakkındaki yeni düşünceleri Yanılmışım Tanrı Varmış kitabının “Tanrı’yı Keşfim” başlıklı II. Bölümünde yer almaktadır. Flew’ün God and Philosophy adlı kitabı demode olmuş bir kaynak olarak ifade etse de, kendisinin de içinde bulunduğu tartışma ortamında bu kitabın hesaba katılmaması imkânsız görünmektedir. Bu sebeple Flew'ün düşünce hayatının bütününü ele alan birisi için bu kitabın önemi tartışılmazdır. Dolayısıyla Flew’ün düşünceleri bu kitaptan yola çıkılarak da irdelenebilir. Hakeza bu kitabın eleştiri konusu olduğu birçok çalışma vardır. Flew’ün din felsefesi yaklaşımındaki en önemli eksikliklerden birinin, rasyonel teoloji eleștirisinden yola çıkarak, Tanrı’nın varlığı iddialarının anlamsız olduğunu iddia ederken imanı tartışma konusu yapmamasının temel itiraz olduğu böyle bir çalışma için bkz. (Polka, 2006). 
Tanrı’nın varlığını kanıtlamadığını düşünmektedir. O, özellikle Leibniz’in yeter sebep ilkesine dayanan imkân kanıtının kozmolojik kanıt içerisinde önemli bir yere sahip olduğunu belirtmiştir. Ona göre yeter sebep ilkesinin fenomenal düzeyde bulunması ne kadar mümkünse, kendi kendinin sebebi olan ilk sebebin var olma imkânı o kadar kanıtlanamaz bir durumdur. Yani evrenin kendi dışında bir sebebinin olması hem mantıksal açıdan hem de bilimsel açıdan imkânsızdır ve evren, içinde barındırdığı özelliklerle ancak kendisiyle açıklanabilecek bir yapı arz etmektedir. Kısaca evreni büyük bir obje gibi değerlendirip ona sebep aramak gereksiz bir uğraştır (Flew, 2005: 82-88). Ayrıca imkân kanıtı, ontolojik kanıtla bağlantılıdır. Buradan yola çıkarak o, kozmolojik kanıtın geçerli bir forma sahip olmadığını düşünmektedir. Çünkü bahsedilen bu durumun telafisi olacak bir eksiklik olmadığ mümkün olmadığı aşikârdır (Flew, 2005: 97).

Teist geleneğin en önemli kanıtlardan biri olan teleolojik kanıtın da Tanrı́nın varlığını kanıtlayamadığını öne süren Flew’a göre evrendeki her şeyde bir düzen ve amacın olmasını tabiatüstü bir varlığa atfetmenin, duygusal bir iddia olmanın yanında belirli sorunları barındırması kaçınılmazdır. Çünkü doğaya bakıldığında böyle bir amacın olduğu çıkarımını yapmamıza yarayan her hangi bir kanıt yoktur. Böyle bir evrende insanların ve hayvanların belli ölçüde gayesel bir hayat sürmeleri kabul edilse dahi her şeyin bu çerçevede değerlendirilmesi söz konusu olamaz (Flew, 2005: 64-65). Bu durum ancak insan zihnindeki sebep-sonuç ilişkisinin zorlama yorumunun bir tezahürüdür. Dolayısıyla ona göre evrende var olan düzenden bir düzenleyici fikrine sıçrama, teolojideki kafa karışıklığının sonucudur. Çünkü tasvir ettikleri aşkın, evrenin dışında var olan düzenleyici Tanrı’nın hiçbir anlamsal değeri yoktur (Flew, 2005: 78). Aslında Flew'ün bu itirazlarının bir benzeri David Hume tarafından dile getirilmiştir. O, insan eseri şeyler ile dünyanın benzer şeyler olduğu düşüncesinin yanlış olduğunu, gayeselliği tün evrene yaymanın anlamsız olacağını ve neden kavramının maddi dünya dışında aynı şekilde değerlendirilemeyeceğini ileri sürmüştür (Hume, 1980: 4-16) Dolayısıyla düzenin var olmasından Tanrı’nın yani düzenleyicinin var olduğu fikrine gitmek mantıksal bir hatadır. Flew’a göre düzenden düzenleyici fikri çıkarılan argümanda, sıradan ve garip bir şekilde, her yönüyle aşikârmış gibi şeylerin kendi doğal eğilimleriyle açıklanamayacağı görüşü savunulmaktadır. Oysa şeyler hakkında yapılacak her açıklama yapay fenomenleri konu edinir durumdadır. Bu durumda bahsedilen argümanın formu, doğal teoloji çerçevesinde ortaya konulmuş sıradan ve basit bir açıklamadır (Flew, 2005: 69-72).

\subsection{Kötülük Meselesi}

Kötülük meselesi din felsefesinin en önemli ve içinden çıkılamaz problemlerinden birisidir. Kötülüğün varlığını kabul edenler ve etmeyenler, bu mevzuda çetrefilli birçok problemle yüzleşmek zorundadır. Kötülük meselesi bir yandan ateist için Tanrı̉nın var olmadığı noktasında gerekçe sağlayabilirken diğer yandan dindarın iman kriziyle karşı karşıya gelmesinin müsebbibi olabilir. Bu meselenin ciddiyetine binaen, kötülük olgusunun olmadığını kabul edenler görüşlerini temellendirmek zorunda olduğu gibi kötülük olgusunun varlığını kabul edenler ya ateizme sürüklenmek ya da göreceli de olsa 
ikna edici bir teodise ile bu olguyu anlamlandırmaya çalışmak zorunda kalmıştır.

Flew, her ne kadar bir ateistin Tanrı̉nın yokluğunu kanıtlama sorumluluğu olmadığını düşünse de ona göre Tanrı’nın var olmadığını kanıtlayan ve savunma pozisyonunda olanların argümanlarını ikna edicilikten alı koyan en önemli şey kötülük meselesidir. Geleneksel Hıristiyan düşüncesindeki düşüş ve ilk günah inancının ya da daha büyük iyilikler için gerekli ölçüde kötülük olması gerektiği (Leibniz, 2013: 380-387) söyleminin hatta metafiziksel bağlamda kötülüğün bir gerçekliğinin olmadığı (Augustine, 2013: 368-372). düşüncesi vb. argümanların bu meselede kesin çözümü sağlamadığını ileri sürmektedir. Mesela daha yüksek düzeyde iyiliklerin varlığg için belli derece kötülük olması gerektiği varsayımı kabul edilse dahi bunu bütüne yaymak ve tüm kötülüklerin izah edildiğini varsaymak ona göre mantık dışı bir tutumdur. Aynı şekilde bağışlanma için neden acı çekme gerektiği ya da cesur veya dayanıklı olmak için niçin sıkıntılara katlanmak gerektiği mantıksal düzlemde açıklanamamıştır. Nihayetinde o, bütün bu kötülüklerin telafi edildiği ya da edileceği düşüncesinin, kendisini ve bu meseleyi hala büyük bir sorun kabul eden birçok kişiyi ikna etmediğini söylemektedir (Flew, 2005: 55). Dolayısıyla Tanrının çocukları ve ebedi hayatın mirasçıları olması bakımından, çok önemli kötülüklerin insanın iyiliğe ulaşmasının zorunlu koşulu olduğu (Hick, 1990: 4047) ve Tanrı’nın bize çok değerli bir özgürlük verdiği fakat insanın bunu suistimal ettiği, dolayısıyla kötülüklerin hesaplanamayan şekilde gerçekleşmesinin sebebinin bu durum olduğu (Lewis, 1940: 121) yönündeki görüşlerin alışılagelmiş iddialar olduğuna dikkat çekmektedir (Flew, 2005: 55).

Aslında kötülük meselesinde Flew’ün üzerinde durduğu temel konu, bu meselenin çözümü için sunulmuş olan özgür irade savunmasıdır. Ona göre özgür irade ve nedensel determinizm teistlerin iddia ettikleri gibi birbiriyle uyuşmaz değildir. Çünkü belli özgür eylemlerin önceden tahmin edilmesi ya da her hangi bir illiyete bağlı olarak açıklanabilir olması çelişki barındırmaz. Buradan yola çıkarak Flew, eylemlerin hem özgür şekilde seçilmesi hem de illiyete dayalı sebeplerle belirlenmesinin mümkün olduğunu, bununla birlikte tüm insanların özgür iradeleriyle sürekli doğru seçimler yapabileceğini belirtir. Böylece Tanrı hakkında konuşmada özür irade savunmasının çelişki barındıracağını ve buna bağlı olarak böyle bir savunmanın ileri sürülemeyeceğini iddia eder. Çünkü o, Tanrı'nın teistlerin kabul ettikleri gibi mutlak kudret sahibi olarak ele alınması durumunda, sürekli doğruyu yapabilen insanlar yaratabileceğini düşünür. Neticede o, özgür irade savunması ile mutlak kudret sahibi Tanrı düşüncesindeki çözümsüzlüklerin, yaratıcı Tanrı düşüncesine olumsuz yansımalarının ve yıkıcı etkisinin olduğunu savunmaktadır (Flew, 1955: 144-169).

Bu düşünceler paralelinde Flew, özgür irade ile yaratma doktrininin arasında tutarsızlık olduğunu ileri sürmüştür. Bu ikisi arasında tutarsızlık olmadığını savunanların ilk söylediği şey, bizim Tanrı’nın yarattı̆̆ı varlıklar olduğumuz ve bir kimsenin özgür olarak eylemde bulunmasıyla baskı altında eylemde bulunması arasında insani açıdan bakıldığında önemli bir fark olduğudur. Fakat Flew’a göre insan bu konudaki değerlendirmelerini dünyevi alanda ve teorik olmayan çerçevede yapmaktadır. Tanrı’yı her şeyin temeli 
olarak ele almak ve her şeyi yaratanın o olduğunu iddia etmek, insani açıdan sorunlara yol açacaktır. Bu durumda insan bu evrende geçici olduğunu düşünerek, bu dünyanın yanılsama olduğu algısına kapılacak ve özgür birey olarak kendisini inkâra kadar gidecektir. Yaratılış düşüncesinin dini metinlerde bu denli işlenmesinin amacı da budur ve insan tahakküm altına alınmak istenmektedir (Flew, 2005: 173). Bu nedenle Flew, her hangi bir anlamda insanın Tanrı’nın yarattığ 1 bir varlık olmasıyla, onun özgür seçimde bulunabileceği fikrinin aynı anda söylenemeyeceğini belirtmektedir. Böylece özgürlük kavramının özelikle Hıristiyan inancında geçen haliyle önceden belirlenmemiş ve tahmin edilemeyen eylemleri içerecek şekilde kullanılamayacağını, yani kavramın daha zayıf bir anlamda ele alınabileceğini işaret etmektedir. Bu şekilde özgürlük kavramının en sıradan anlamında, önceden belirlenmiş ve tahmin edilebilir iyi ya da kötü eylemlerde özgür şekilde bulunabilme imkânı doğacaktır. Fakat kötülük meselesi bağlamında, bu sıradan anlamdaki özgürlük düşüncesi ile mutlak iyi Tanrı’nın mutlak özgür varlıklar yarattığı düşüncesi hala tutarsızlık barındıracaktır (Flew, 2005: 56).

Alvin Plantinga, Flew’un bu görüşlerinin özgür irade savunmasının geçerliliği konusunda her hangi bir olumsuz etkisinin olmadığını iddia etmektedir. Ona göre ilk etapta Flew’ün "illiyete dayalı belirlenmiş eylem"den ne kastettiği müphemdir. Bununla birlikte bir eylemin hem illiyete dayalı olarak belirlenmesi ve özgür şekilde yapılabilirliği çelişki barındırmaktadır. Özgür irade savunucusunun tüm özgür eylemlerin illiyete dayalı olarak gerçekleşmediğinde ısrarcı olabileceğini belirten Plantinga, Tanrı’nın insanı özgür kıldığını ve insanın özgür iradesiyle hem iyiliği hem de kötülüğü işleyebildiği dünyanın, özgür olmadan yalnızca iyiyi işleyebildiği dünyadan daha değerli olduğunun ileri sürebileceğini iddia eder. Bunun aksine Flew'ün hem özgür ve hem illiyete bağlı olarak belirlenmiş şekilde iyi ve kötü eylemde bulunan insanların bulunduğu bir dünyanın, aynı belirlenimle şekillenen özgür şekilde sürekli iyiyi işleyen insanların bulunduğu dünyadan daha değersiz olduğu savunulabilir. Bu açıdan bakıldığında Plantinga, Flew’ün haklı ya da haksız olduğunun belirlenemediği ve itirazının zararsız olduğu sonucuna varmaktadır (Plantinga, 1975: 188-190).

\subsection{Kanitlama Sorumluluğu}

Tanrı́nın varlığını kabul edip etmemede kanıta sahip olma tartışılan en önemli meselelerden birisidir. Ateistler kanıtlama zorunluluğunun teistlerde olduğunu savunurken, Tanrı inancına sahip fakat önermesel bağlamda kanıtlamanın mümkün olmadığını bu nedenle kanıt getirme uğraşının boş bir çaba olduğunu iddia eden düşünürler de vardır. Aynı zamanda teistlerin önemli bir kısmı farklı argümanlarla bu sorumluluğu yerine getirme çabası içerisindedir. ${ }^{8}$

Flew, Tanrı̉nın varlığıyla ilgili bir tartışmanın ateizm varsayımıyla başlaması gerektiği ve kanıtlama sorumluluğunun teistlerde yani onaylayanda olduğunu iddia etmektedir

8 Bu düşünürlerden en önemlisi Richard Swinburne'dür. O, akılcı tutumu benimseyerek Tanrı’nın varlığını çeşitli argümanlarla kanıtlayabileceğini düşünmektedir. (Swinburne, 1979; Swinburne, 1981). 
(Flew, 1972: 36). Flew'ün ateizm varsayımıyla kastettiği şey Tanrı’nın varlığı tartışmasında negatif ateizmin başlangıç noktası olarak kabul edilmesidir. Böylece pozitif ateizm ve teizm arasında, tarafsızlık ilkesince (principle of neutrality) hareket edilecektir. Fakat bu noktada Tanrı'nın varlığını iddia eden varsa bunu kanıtlarla temellendirmelidir. Yani teist hem önerdiği Tanrı kavramını savunmalı hem de ona inanılmayı sağlayacak yeterli kanıtı sağlamalıdır. Onu kanıtlamadığı sürece var olduğunu iddia etmemelidir. Pozitif ateizm de teizmin konumundadır. Pozitif ateist de olumlayıcı (Tanrı'nın var olmadığı noktasında iddiada bulunmak anlamında) olduğu için o da iddiasını kanıtlamak zorundadır. Kısaca ateizm varsayımının ilk adımı tarafsızlık ikincisi ise delilciliktir (Odoj, 2014: 97-114).

Genel olarak ateistlerin savunduğu bu argüman, kendilerinin Tanrı’nın yokluğunun kanıtlanması gibi bir zorunluluğa sahip olmadıklarının ilanıdır. Her hangi bir şeyin yokluğunun kanıtlanmasının imkânsız olduğunu düşündüğümüzde, bu argümanın doğru olduğunu söyleyebiliriz. Fakat unutulmaması gereken önemli husus, bir şeyin yokluğunun kanıtlanamaması onun var olmadığını göstermez (Kütük, 2010: 60-61). Kısacası Flew’ün öne sürdüğ̈̈ iddiada haklı olduğu söylenebilir. Ancak, bu durum onun evren, insan, hayat, bilinç vs. konularda ikna edici açıklamalar yapma noktasındaki sorumluluğunu ortadan kaldırmayacaktır. Daha önemlisi Flew’ün kendisinin ileri sürdüğü ateizm varsayımı ilkesince hareket etmediği ve kendisiyle çeliștiğini görülmektedir. Çünkü özellikle kötülük meselesini işlerken, bu problemin Tanrı’nın var olmadığının kesin kanıtı olduğunu ileri sürmüştür. Böylece pozitif ateist tutum sergileyerek tarafsılılk ilkesine göre hareket etmemiştir.

\section{2. İKİNCİ DÖNEM: TANRI İNANCINA DÖNÜŞ}

"Kanıtların götürdüğü yere git” ilkesince hareket eden Flew, düşünce hayatının ikinci evresi olarak tanımladığımız dönemde, evrenin zekâ sahibi bir varlık tarafından var edildiğine, evrenin karmaşık kanunlarının onun varlığına işaret ettiğine, bu varlığın hayatın ve çoğalmanın kaynağı olduğuna inandığını ifade etmektedir. Bu inancına ulaşmadaki gerekçelerini ana başlıklar halinde sıralarsak, bunların bilim ve yenilenen felsefi iddialar olduğu söylenebilir. Zaten Flew, Tanrı inancına dönüşte her hangi bir dinin etkili olmadığını, kişisel her hangi bir tecrübeyi de yaşamadığını ileri sürer. Ona göre bilim, doğanın Tanrı’ya işaret eden üç yönünü göstermektedir. Bunlardan ilki doğanın kanunlara uyumu, ikincisi bu doğada var olan hayatın kendisi, üçüncüsü ise evrenin varlığıdır (Flew, 2004: 90).

\subsection{Doğa Kanunları}

Bilimsel gelişmelerin Tanrı inancına dönmesindeki temel etkenlerden birisi olduğunu belirten Flew, doğa kanunlarının bu konuda düşünülmesi gereken ilk husus olduğunu ifade eder. Onun doğa kanunundan kastı doğadaki düzendir. Bundan dolayı onun için Tanrı'nın varlığına ilişkin muhtemel en önemli kanıt tasarım kanıtı olmuştur. $O$, ateist olduğu dönemde bu kanıtı eleştirmesine rağmen bu argümanın doğru formüle edildiğinde Tanrı’nın varlığı hakkında ikna edici bir nitelik kazanacağını belirtir (Flew ve Habermas, 
2007: 200). Bu kanıtı onun nezdinde ikna edici kılan da doğa kanunlarının kaynağı konusunda modern bilim adamlarının tasarım hakkındaki olumlu görüşleri ve hayatın kaynağı ile birlikte üreme meselesinde dini izaha karşı olan bazı bilim adamlarının ikna edici bir argüman ortaya koyamamasıdır (Flew, 2004: 95). Ancak akıllı tasarımı kabul edenler, Darwinci açıklamayı reddetmekle birlikte, kurallılık ya da şans kavramlarının yetersiz açıklama olduğundan dolayı tasarımın tek açıklama olarak kaldığını ifade ederler. Fakat bu tasarım teorisinin, en iyi izah olup olmadığını bize kanıtlayan deneysel test edilebilir bir hipotezin olup olmadığı tartışmalıdır (Peterson vd., 2006: 129-131).

Doğadaki düzenden başka, bu düzenin matematiksel, kesin ve evrensel olarak devamlılığına önem veren Flew, Newton, Einstein, P. Davies ve Heisenberg gibi bilim adamlarının doğanın bu şekilde bütün haline nasıl geldiği sorusuna verdikleri cevapta Tanrı aklına işaret ettiklerini vurgulamaktadır. Ona göre bu durum sadece teist bilim adamlarında rastlanan bir şey değildi. Mesela o, Stephen Hawking'in pek çok modern bilim adamı gibi doğanın kanunlarının kaynağı ve devamı sorusuna Tanrı’yı bir cevap olarak koyabileceğimizi kabul ettiğini belirtmektedir. Bu görüşlere dayanarak Flew, evrenin varlığı ve düzenini kesin olmayan iddialara dayandırmaktansa, daha kolay bir açıklama olan Tanrı’ya bağlamanın daha anlaşılır bir durum olacağını düşünmektedir (Flew, 2004: 97). Flew bu durumu Davies'in açıklamalarıyla gerekçelendirmeye çalışır. Davies, aslında ateist bilim adamlarının dahi düzeni kabul ettiğini, tasarım düşüncesi her ne kadar evrenle ilgili soruları tam olarak yanıtlayamasa da bilimin ancak Tanrı'yı kabul eden bir anlayışla ilerleyebileceğini belirtir (Flew, 2004: 108).

Bu noktada o düşünce tarihinde fikirleri tartışılan ve birçok kişi tarafından ateist olarak nitelendirilen Einstein’ın doğadaki mükemmel düzene dikkat çekerek yüce bir tasarımcıya işaret ettiğini ileri sürmektedir. Ona göre Dawkins gibi modern ateist bilim adamları Einstein'ı kendi düşüncelerine temel oluşturmak için ateist olarak nitelendirmektedirler. Fakat Einstein mükemmel bir düzenin varlığını kabul etmiş ve yüce bir tasarımcıya işaret etmiştir (Flew, 2004: 99-100).

Flew, modern bilimsel ilerlemenin ve teist bilim adamlarının görüşlerinin Tanrı’nın varlığını açıklamada kesin ikna edicilikten uzak olduğunu düşünmüş olmalı ki, Swinburne’ün Dawkins'e verdiği cevaptan memnuniyetini dile getirerek, onun felsefi temellendirmelerinden yardım almaktadır. Swinburne’e göre doğa kanunu demek bütün organların belirli bir biçimde hareket etmesi anlamına gelmekle birlikte, bu düzeni maddenin eyleminden kaynaklanan bir olay olarak açıklamanın, doğanın kanunlarının işleyişini bireysel bir Tanrı'ya dayandırmaktan daha zor bir varsayımdır (Swinburne, 2004: 13-18). Sonuç itibariyle Flew, çeşitli bilim adamı ve filozofların görüşlerine dayanarak, evrenin kanunlarının her hangi bir gerekçesi olmadığı, evrenin anlamsız olduğu yönündeki ateist iddiadan uzaklaşmış, bilim adamlarının gerçekliğin kavramsal ve mantıksal izahını ikna edici şekilde yaptıklarını ileri sürerek, doğa kanunlarının Tanrı́nın varlığı ile bağlantılı olduğunu kabul etmiştir. 


\subsection{Hayatın Kaynağı ve İdamesi}

Doğanın kanunlarına, bu kanunların sürekliliğine bağlı olarak gerçekleşen ve sürdürülen hayatın varlığı, Flew için Tanrı'ya işaret eden diğer bilimsel kanıttır. Bu durum hassas ayarlanmış evrenin varlığına dayandırılır. Bilimsel kanıt olarak bu durumun karşılığı antropik ilke (insancıl ilke) olarak nitelendirilmektedir. İnsancıl ilkenin iki farklı yorumu yapılabilir. Bunlardan ilki teist bilim adamlarının, hayatın varlığına sebep olacak hassas ayarın ilahi tasarımın kanıtı olduğunu iddia etmeleri (Betty ve Cordell, 2013: 297-309), ikincisi ise ateist bilim adamlarının, sayısız evren içinde bizim evrenimizin hayata uygun koşullar taşıdığını söylemeleridir. Bizim yaşadığımız evrenden başka evrenlerin de var olabileceği düşüncesinden hareketle çok evrenler tezine dayanan ateist yaklaşım, 'eğer çok sayıda evren varsa Tanrı yoktur, hassas denge olasılık ve rastlantıya dayalı olarak açıklanabilir' şeklinde özetlenebilir (Collins, 2014: 45). Flew, ilahi tasarım karşısında ortaya atılan çoklu evren kuramının, aslında bu hassas ayarlanmış evrenin kaynağının Tanrı olduğu görüşünü ortadan kaldırmadığını belirtmektedir (Flew, 2004: 112). Aynı zamanda dikkat çektiği diğer husus hiçbir önemli bilim adamının bu hassas ayarın şans eseri tek bir evrende meydana geldiğini iddia etmemesidir. ${ }^{9}$

Flew, antropik ilkeye dair iddialar karşısında söylenebilecek şeylerin üç şekilde açıllanabileceğini ileri sürmektedir. İlk olarak, belirli kanunlara sahip bu evrende hayatın var olduğu ve bu kanunların farklı olması halinde hayatın devamlılığının sağlanamayacağı aşikârdır. İkinci olarak, evrende var olan mevcut kanunların hayatın devam etmesini sağlamasının hayatın kaynağı sorusuna mutlak cevap vermediği ve bu kanunların hayatın başlaması için gerekli fakat yeterli olmadığıdır. Son olarak ise, kendilerine özgü kanunları olan birden fazla evrenin olma olasılığı, bu evrenlerin gerçekten var olduğunun kanıtı değildir (Flew, 2004: 114). Hakeza onun için birden fazla evren olması durumunda bile doğanın kanunlarının kaynağı halen açıklanamamaktadır. Birçok evren olsa bile bütün bu evrenlerin tamamında hüküm süren kanunlar neden ve nasıl ortaya çıkmışlardır? Doğa kanunlarının ve hayatın büyük patlamadan sonra tesadüfî meydana geldiğini iddia etmek, Flew’a göre doğa kanunlarının kaynağına işaret eden ikinci dereceden açıklamalardır. Çünkü doğa kanunlarının evrimi veya değişimleri belirli bir yasaya göre şekillenmektedir. Yani Tanrı'nın yokluğuna ya da gereksizliğine kanıt olarak sunulan tesadüfî oluş düşüncesi bu kanunların kaynağı probleminin cevabı değildir (Flew, 2004: 115).

Hayatın kaynağı sorununa ilahi akıl ile cevap vermekle birlikte bu görüşünü son bilimsel gelişmelerle teyit eden Flew, kendiliğinden varlığa gelmeyi benimseyen kuramların, kanıtlama gücü yok denecek kadar zayıf görüşler olduğunu belirterek biyologların DNA incelemelerinin hayatın başlangıcının ilahi aklı gerektirdiğini kanıtlayan en önemli kanıt olduğunu ileri sürmektedir (Flew, 2004: 119-124). Bununla birlikte hayatın kaynağı probleminin sadece bilim adamlarının cevaplaması gereken bir şey olmadığını

9 Flew’un antropik ilke hakkındaki görüşlerini temel aldığı bilim adamlarından bazıları Freeman Dyson, Martin Rees, John Barrow ve John Leslie’dir. Antropik ilkenin Tanrı’nın varlığına kanıt olduğunu açıklarken dayandığı nadir kaynaklardan biri için bkz. (Leslie, 2001) 
söyleyerek felsefi açıdan meseleye bakılmasının zorunluluğuna dikkat çekmektedir. Canlı varlıkların özgün amaçları, kodlanmış kimyaları ve üreme kabiliyetlerinin kendiliğinden oluşamayacağı gerçeğinin, canlı olmanın anlamı ve üremenin kaynağının materyalist bakış açısıyla açıklanamayacağının önündeki en büyük engel olduğunu ileri sürmektedir. Flew, bu noktada Aristonun teolojinin canlı varlıkların hayatları açısından gerekli olduğunu söyleyen teolojik hayat düşüncesini temel alarak, amaçlı ve üreyen hayatın kaynağı için yapılabilecek tek açıklamanın sonsuz bir aklın varlığı olduğunu iddia etmektedir (Flew, 2004: 124).

\subsection{Evrenin Varoluşu}

Evrenin varoluşu meselesinde Flew’ün görüşlerini şekillendiren iki temel soru vardır. Bunlardan ilki bir şeyin yoktan var olmasının imkânı olup olmadığı, ikincisi ise ilk soruya verilecek cevabın evrenin nasıl meydana geldiği konusundaki görüşü ne şekilde etkileyeceğidir. Flew, ateist olduğu dönemde evrenin başlangıcı ve sonu olmayan mutlak bir gerçek olduğunu kabul ettiğini, büyük patlama kuramıyla birlikte bu düşüncesinin değiştiğini ifade etmektedir (Flew, 2004: 128). Büyük patlama kuramı sonucunda evrenin bir başlangıcı varsa, bu başlangıcın sebebinin ne olduğu sorusu onun düşüncesinin kökten değişmesini sağlamıştır. Fakat kendisinin de kabul ettiği gibi ateistler bu kuramı fiziki bir açıklama olarak görürler. Mesela Quentin Smith, büyük patlama kozmolojisinin Tanrı'ya inanmakla bağdaşmaz olduğunu savunmaktadır. Çünkü alemin ilk hali olan büyük patlamada hayatın varlığı için olumsuz şartlar bulunmaktadır. Bu nedenle bu patlamanın hayatla donatılmış aleme yol açacağını gösteren her hangi bir fiziksel kanıt bulunamaz. Sonuçta büyük patlama kendiliğinden oluşmuş bir olaydır (Smith, 1992: 225). Buna karşılık Tanrı’ya inananlar ise evrenin Tanrı tarafından yaratıldığına kanıt göstermiştir. ${ }^{10}$

Flew, Hawking'in büyük patlamadan öncesinin bilimsel veya fiziki açıklamasının şimdilik yapılamadığı, hatta evrenin varlığının kendinden olduğu varsayımıyla hareket edildiğinde, ona başlangıç ya da son izafe edilemeyeceği dolayısıyla bu durumun yaratıcı düşüncesini gereksizleştirdiği görüşünden yola çıkarak, fiziğin son etapta agnostik kalması gerektiği düşüncesine varmıştır. Yani şayet büyük patlama varsa ona neyin yol açtığını bulmak fiziki olarak imkânsızdır. Flew, bu durumda söz konusu meselenin bilimsel olmaktan çok felsefi açıdan değerlendirilmesi gerektiği sonucuna ulaşmıştır (Flew, 2004: 130). O, bilimsel çıkmazdan kurtulmak için David Conway'in The Rediscovery of Wisdom ve Swinburne'ün The Existence of God (Swinburne, 2004) adlı eserlerinde yer alan kozmolojik argümanın felsefi yorumlarına ve bu argümana yönelik eleştirilerin cevaplarına başvurmuştur. Özellikle Swinburne'ün kozmolojik argümanının umut verici ve muhtemelen doğru olduğunu söylemektedir (Flew, 2004: 135).

10 Craig, ortaçağ islam filozoflarından esinlenerek oluşturduğu kelam kozmolojik argümanının temelini büyük patlama teorisiyle kurar. Bu sebeple alemin başlangıcına dair büyük patlama modeline ve termodinamiğin ikinci kanununa başvurur. (Craig, 1979). Yoktan yaratma teorisiyle uyumlu olan hudûs delilinin kelam literatüründeki gelişimi için bkz. (Yıldırım, 2013) 
Swinburne, kendi kozmolojik kanıtını oluştururken, evrenin bir başlangıcı olup olmamasının yani büyük patlama gibi bir olayın gerçekleşip gerçekleşmediğinin belirleyici olmadığını öne sürer. Bu durumda evrenin bir başlangıcı olup olmaması onun kanıtını etkilenmeyecektir. $\mathrm{O}$, bu noktada evrenin bilimsel olmayan bir açıklaması olabileceği düşüncesinden hareket etmektedir. Bir bakıma bilimin evrenin varlığını kesin sonuçlarla açıklayamadığı düşüncesi onun kanıtının temel dayanak noktalarından biridir. Aynı zamanda o, evreni açıklamada bilimin tıkandığı noktada dinin devam ettiğini söyleyerek teizmin, evrenin kişisel bir açıklamasını yapmada her daim ısrarlı olduğunu vurgulamaktadır. Çünkü bilim bize evrenin bir düzene sahip olduğunu belli bir noktaya kadar varan nedenler dizisiyle açıklar. Fakat din bu nedenlerin ötesindeki daha derin nedeni varsayar. Bu bilimi inkâr etmek değil, bilimin açıklama nedenini açıklamaktır (Swinburne, 2004: $120 \mathrm{vd}$ ).

$\mathrm{Bu}$ noktada biz büyük patlama kuramının bilimsel açılımını tartışmayacağız. Şunu belirtmek gerekir ki, bu kuramdan yola çıkılarak kurulan argümanın felsefi yorumlarına ciddi itirazlar yöneltilmiştir. Bunlardan bazıları, alemin yoktan yaratılmasına sebep olacak failin neden şuurlu bir varlık olarak tanımlanması gerektiği, şayet bir ilk neden tanımlanacaksa bunun birden fazla olup olmayacağı ve farz edilen nedenin de bir nedeni olup olmadığı vb. hususlarıdır.

\subsection{Tanrı Anlayışı ve Ateizm Eleştirisi}

Ateizmden Tanrı inancına rasyonel yolculuğunu tamamlayan Flew’ün nasıl bir Tanrı tasavvur ettiği bu yolculuğun en önemli adımlarından birisidir. O, Habermas ile münazarasında Aristo’nun Tanrı'sına inandığını söylese de, Aquinas’ın Tanrı’nın varlığını ispatlamada kullandığı beş kanıtı Aristo’dan aldığını, şayet Tanrı’nın varlı̆̆ını ispatlamışsa bu Tanrı’nın Hıristiyanlığın Tanrı’sı olduğunu ileri sürmüştür. Çünkü ona göre, nizam delili Tanrı’nın varlığını kanıtlamak için yeterlidir (Tarakçı, 2006: 28-42). Daha önce görüldüğü gibi ateizmden vazgeçişinde daha çok nizam delilinin son hali olarak nitelendirilebilecek hassas ayar argümanından ve Aristo'nun Tanrı düşüncesinden yola çıkmaktadır. Böylece hem teizme hem de deizme göz kırpmış hem de Hıristiyan Tanrı anlayışına çok da uzak olmadığını ima etmiştir. Mesela Piskopos Wright’ın İsa'nın Tanrı'nın oğlu olduğu, Tanrı’nın oğlu vasıtasıyla insanlara göründüğü, İsa’nın yeniden dirilişi gibi konulardaki düşünceleri karşısında mantıken imkânsız şeyler dışında, her şeye kadir bir gücün yapabileceği şeylere sınır çizilemeyeceğini belirtmektedir. Onun bu kitaptaki son cümlesi, ilahi gücün her şeyi yapabileceği olmuştur (Flew, 2004: 194).

Fakat bununla birlikte kötülük problemi, vahiy ve ahiret inancı gibi hususlar Flew’ün Tanrı anlayışı hususundaki düşüncelerini etkilemiştir. Çünkü o, ateizmden Tanrı inancına oradan da Hıristiyan inancına dönüş yapıp yapmayacağı sorusuna karşılık, kötülük meselesinden dolayı böyle bir şeyin pek de mümkün olmadığını dile getirir (Flew ve Habermas, 2004: 211). Buna rağmen Habermas, onun Tanrìya ve onun birçok niteliğe sahip olduğuna inandığını söylerken teist olarak nitelendirilebileceğini fakat vahye, mucizelere ve Tanrı'nın insanla herhangi bir ilişki içinde olabileceğine inanmadığını ileri 
sürmesiyle deist olarak ifade edilmesinin daha doğru olacağını belirtir (Habermas, 2007: 433). Bu durum Habermas için Flew’ün vahiy düşüncesini tamamen reddettiği anlamına gelmez. Nitekim Flew, çok hevesli olmasa da vahiy düşüncesine açık olduğunu ileri sürer. Şöyle ki, mesela fizikçi Gerald Schroeder'in Tekvin 1 ile ilgili yorumlarının kendisini etkilediğini ve bilimsel olarak işlenen bu İncil yaklaşımının vahiy ihtimalini artırdığını söylemektedir (Flew ve Habermas, 2004: 199). Bu açıklamalarından dolayı Habermas, onunla mülakatlarındaki farklı düşüncelerinden dolayı, Flew’ün vahye inanma olasılığı bulunduğunu sürekli vurgulamaktadır (Habermas, 2007: 440).

Ayrıca Flew, ölümden sonra bir hayatın var olmadığını, var olmamasını ümit ettiğini söylemektedir. Bu noktada ölüme yakın insan tecrübelerinin örnek olarak verilmesini faydasız bir çaba olarak görmekle birlikte bu yolla cennet ve cehennem doktrinlerinin kanıtlanamayacağını düşünmektedir. Bu tarz tecrübeler çok etkileyici olsa da bu tecrübeyi yaşayanlar, yaşadıkları tecrübeyi ölüm sonrası tecrübe ile karıştırmaktadırlar. Ayrıca bu tecrübeler kanıtlanamaz derecede subjektiflik içermektedir. Oysa ölüme yakın tecrübeler, mesela kalp ya da beyin fonksiyonlarının durduğu kimselerde ve anlarda kanıtlanabilseydi, Flew için bu durum ahiretin varlığı hususunda sağlam bir kanıt olmuş olurdu (Flew ve Habermas, 2004: 206).

Buna rağmen kendisi mucizelere inanmasa da onun için, İsa’nın yeniden dirilişi, diğer dinlerdeki pek çok mucizevi olaydan daha mantıklı ve inanmak için evlâdır. O, şayet Tanrı'ya mucizeler yoluyla inanılacaksa bunun herkesi ikna edici tarzda mucizelerle mümkün olması gerektiğini ima ederken, Hıristiyanların İsa’nın yeniden dirilişine inanması noktasında geçerli sebepleri olabileceğine vurgu yapar. Şöyle ki vahyin Tanrı’sına rasyonel olarak iman etmiş birisi için bu tarz inançlar rasyonel temelli inancın ikincil yansımalarıdır (Flew ve Habermas, 2007: 209-210). Burada dikkat çekilmesi gereken çelişki, mucizelere inanmayan Flew'ün rasyonel temelli Tanrı inancına sahip olduktan sonra inanılan yeniden dirilme olayının kabul edilebilirliğine işaret ederken, Hıristiyanlığ 1 diğer dinlere nazaran daha makul gösterme çabasıdır. Bu durumun bize, Flew'ün bir yandan deist olduğunu söylerken diğer yandan Hıristiyan inancının kendisi üzerindeki geçmişinden gelen etkisine göre düşüncelerini geliştirdiği yorumunu yapma hakkını verdiğini düşünüyoruz. Böylece kanıta göre hayatını yönlendirdiğini iddia eden Flew, bilinçaltı ve kültürel faktörlerden kaynaklanan sebeplerden ötürü subjektif yorumlarda bulunabilmekte ve kendisi ile çelişebilmektedir.

Ayrıca Flew'un bu açıklamaları reformist epistemoloji savunucularının iddialarını çağrıştırmaktadır. Reformist epistemolojiye göre Tanrı inancı temel bir inançtır. Her türlü inancın kanıtla temellendirilmesi gerektiği düşüncesine karşılık, bu anlayışta kanıtla temellendirilememesine rağmen, bizim için değişmez ve temel olan inançlar olduğu kabul edilir. Tanrı inancı böyle bir inançtır. Bu nedenle kendisinin temel inanç olarak kabul edildiği Tanrı inancına dayanarak oluşmuş birçok inanç da rasyonellik niteliği kazanır (Mehdiyev, 2008: 66-80). Flew, Hıristiyanlık hususundaki düşüncelerini reformist epistemoloji taraftarlarından etkilenerek ileri sürmüş olabilir. Fakat şayet bu durum Hıristiyanlık için geçerliyse tüm dini inançlar için de geçerli olmalıdır. Aslında daha ciddi 
sorun Flew'ün reformist epistemolojide dile getirilen düşünceler serdetmesine rağmen, bu yaklaşımın tenkit ettiği hatta meydan okuduğu tüm inançların temellendirilmesini öngören klasik temelciliği savunmasıdır. Çünkü klasik temelcilik, tüm inançlarımızın kendilerinden en küçük dahi şüphe edilemeyecek şekilde kanıta dayandırılması gerektiğinin ileri sürüldüğü yaklaşımdır. Aydınlanmacı rasyonel kanıta dayalı doğal teoloji bu yaklaşımın bir ürünüdür (Mehdiyev, 2008: 68).

Ateizm eleştirisi Flew’ün kendi düşüncelerinin tamamlanması için ayrı bir öneme sahiptir. Dolayısıyla o, ateist kanıtların irdelenmesi için Roy Abraham Varghese'den bir çalışma yapmasını istemiştir. Bu çalışma Flew’ün bahsi geçen kitabının ekler bölümünde "The New Atheism: A Critical Appraisal of Dawkins, Dennett, Wolpert, Haris and Stenger" (Yeni Ateizm: Dawkins, Dennett, Wolpert, Haris and Stenger’a Eleştirel Yaklaşım) başlığıyla kendisinin de tasdik ettiği düşünceleri içerecek şekilde yer almıştır.

Varghese, teist ve ateistlerin bir şeyin var olması için öncesinde başka bir şeyin olması gerektiği, ebediyen var olan bir gerçekliğin nasıl meydana geldiği sorusunun cevabında böyle bir gerçekliğin meydana gelmediği, aksine her zaman var olduğu noktasında hemfikir olduklarını belirtir. Varghese, ateistlerin evrenin ebediyen var olduğu iddialarına karşılık, bu ebediyen var oluşun kaynağını açıklayamadıklarını ve hiçbir zaman da açıklayamayacaklarını ileri sürer. Hayat denen şeyin nasıl başladığı hususunda Dawkins ve diğerlerinin yetersiz açıklamalara sahip olduğunu söyleyen Varghese, evrimle açıklanan materyalist hayat felsefesinin ve bilim görüşünün, Flew’ün da bahsettiği insancil ilkeyi görmezden geldiğini belirtir (Flew, 2004: 154 vd). Buna karşılık Dawkins doğal seçilimin, tüm bilginin nereden geldiği problemini çözmenin tek yolu olduğunu vurgular. Bu nedenle teistlerin bahsettiği tanrı varsayımının insancıl ilkeden yola çıkarak kesin olarak kanıtlanamayacağını iddia eder (Dawkins, 2009: 132)

Ateizmle teizm/deizm arasındaki tartışmaların son döneminde gündemde olan şey, iki tarafın da birbirini salt bilim yoluyla ikna etme çabasıdır. Tabiî ki bu tartışmada felsefi argümanlar da kullanılmaktadır. Ancak, aslında ateistlerin ya da teistlerin sadece bilimsel yolla birbirini ikna etmesinin imkânı sorgulanmalıdır. İki taraf da gerçekten bilimsel verilerin ve kanıtların götürdüğ̈̈ yere mi yönelmektedirler? Ateistler, hayatın nasıl başladığı, evrenin niçin ve nasıl var olduğu, fizik kanunlarının neden böyle olduğu gibi soruların cevabını bilimin gelecekte cevaplayacağını, teistler ise Tanrı düşüncesi olmadan bu soruların ikna edici bir cevabının bulunamayacağını kabul etmektedir. Teistler, ateistlerin bilimin bir cevap bulana kadar susması gerektiği çıkarımını yapabilirler. Fakat yukarıda belirtildiği gibi sorun sadece bilimsel açıdan belirlenebilecek kesin hükümlerin verilip verilemeyeceğidir. Çünkü aynı itirazı ateistler de teistlere yöneltebilir. Onlar, Tanrı̉nın varlığının kesin kanıtlanamadığı, bu nedenle bilimin açıklama durumunun onun varlığının lehine kesin sonuçlara varıncaya kadar teistlerin susması gerektiğini iddia edebilirler. Bu tablo, "bilimsel teoriler belli dönemlerde, belli açıklama tarzlarıdır” (Çınar, 2009: 21) ifadesini kabul edebilme ile ilgili bir durumdur. 


\section{RASYONEL SERÜVENDEKİ TUTARSIZLIKLAR}

Bu bölüme kadar Flew’ün ateist olduğu dönemdeki temel argümanlarını ve Tanrı’ya inanmaya başlamasının epistemolojik dayanaklarını ortaya koymaya çalıştık. Gelinen noktada yapılması gereken, onun ateist dönemde bağlı bulunduğu iddialarına cevap bulup bulmadığını tartışmak ve sunduğu kanıtların "kanıtın götürdüğü yere git” ilkesinin tazammunlarını ne kadar gerçekleştirdiğini irdelemektir. Bu değerlendirmeyi yapmadaki amaç, onun ateizmden Tanrı inancına yolculuğundaki iddialarının tutarlı olup olmadığını sorgulamaktır.

Tanrı hakkında konuşmanın imkânı problemi Flew’ün inanç yolculuğundaki çözülemeyen temel hususlardan biridir. O, Tanrının var olup olmadığı ve kanıtlanması meselelerinden önce Tanrı hakkında nasıl konuşulacağı meselesinin irdelenmesi gerektiği düşünmekteydi. Fakat Flew, ateist olduğu dönemde cevap bulamadığ din dili problemini çözmeden Tanrı’nın varlığını kabul etmiştir. Bu durum kendi düşünceleriyle çeliştiğini göstermektedir. Öte yandan, öyle görünüyor ki; onun Tanrı hakkında konuşmak ile ilgili temel tutumunda mantık hatası vardır. Bir şeyin varlığını kabul etmeden onun neliğini ya da nasıllığını tartışmak hatalı bir tutum olacaktır. Neticede din dili konusundaki ateist iddialarına deist olduğu dönemde tatmin edici cevap veremeyen Flew, sadece bu konuda daha önce ifade edilen görüşleri tekrarlamakla yetinmiştir. Bu konuda görüşlerine başvurduğu düşünürlerden bir tanesi Tracy'dir. Tracy'e göre kişiler bilinçli şekilde hareket eden aracı varlıklardır. Tüm aracıların bilinçli şekilde hareket edebilmesi için bedenli varlıklar olmalarına gerek yoktur. Her eylemi bilinçli olan Tanrı da aracıdır. Fakat o, eylemleri eşsiz olan bir kişilik olduğu için, onun için bütün varlıkları meydana getiren aracı niteliği kullanılabilir (Tracy, 1984: $146 \mathrm{vd).}$

Kötülük meselesi Flew’ün iki hususta çelişkiye düştüğünü göstermektedir. Ateizm varsayımını negatif ateizmle başlatıp, teist ve pozitif ateist tutumları aynı kefeye koyan Flew, negatif ateizm kanadında kalmamış pozitif ateizme uygun argümanlar öne sürmüştür. Bu tablo karşısında onun olumlayıcı iddiaya sahip tarafın kanıtlama yükümlülügüne sahip olduğu düşüncesine göre hareket etmediğini söyleyebiliriz. Bunun en bariz kanıtı kötülük meselesidir. Dahası o, Tanrı́nın var olmadığının en kesin kanıtı olarak gördügü kötülük meselesinin çözülemediğini itiraf etmekte hatta bu doğrultuda her hangi bir dini inanca bağlanamayacağını ve deist olarak kalacağını söylemekteydi. Din dili konusunda olduğu gibi o, bu probleme verilen cevapları sıralamakla yetinmiştir. Bunlardan ilki Tanrı́nın dünyaya müdahale etmediğini savunan Aristotelesçi yaklaşım diğeri de insanların özgür olmasından kaynaklanan kötülük ihtimalini belirten özgür irade savunmasıdır (Flew, 2004: 146). Kısacası "kanıtın götürdüğ̈̈ yere git" ilkesince hareket etmesine ve ateist döneminde en kesin kanıt olarak baktığı kötülük problemini çözememesine rağmen, sonraki dönemde bir Tanrı inancına sahip olması Flew’ün kendi sistemi açısından çelişki doğurmuştur.

Tanrı inancına sahip olma aşamasında öne sürdüğü kanıtlar Flew’ün inanç yolculuğunun en tartışılır mevzusudur. O, Tanrı’ya inanmasındaki en önemli etkenin bilimsel gelişmeler 
ve hayatın başlangıcı, doğadaki düzen vb. hususlarda ateist bilim adamlarının ikna edici cevap verememesi olduğunu belirtmekteydi. Aynı şekilde teist bilim adamlarının düzen ve düzenin devamının açıklanmasında Tanrı'ya baş vurmalarının ateist açıklamaya göre daha kolay anlaşılır olduğunu söylemekteydi. Flew’ün bu düşüncelerinden şu sonuç çıkar ki; aslında tasarım ve düzenin devamı konusunda kesin kanıtlardan ziyade ikna edici açıklama ya da anlaşılması kolay izahlar vardır ve o, bu konuda sadece kesin kanıtlardan ziyade bilimsel gelişmeleri farklı yorumlamaya ve anlamaya meyletmiştir. Özellikle bilimsel gelişmeleri sübjektif bir tutumla kaynak göstermesinde aşikâr bir tezat bulunmaktadır. Çünkü önemli bilim adamlarından hiçbirinin ilahi tasarımcıya atıf yapmadan bu evreni açıklamadığı ileri sürmektedir. Fakat mevcut olgusal durum tam olarak onun iddia ettiği gibi değildir. Kısaca Flew’ün kanıtlara ve bilimsel gelişmelere yönelik sadece bakış açısının değiştiğini söyleyebiliriz.

$\mathrm{Bu}$ nedenle bu bilimsel gelişmeleri, var olan kanıtın daha fazla ayrıntılı şekilde ifade edilmesi bağlamında faydalı fakat Tanrı'nın varlığının kesin kanıtı olarak kabul edilmesinde aşırı iddialı addedebiliriz. 20. yüzyılda gelişen Big Bang kozmolojisinden sonra, tasarım kanıtının son şekli olarak ortaya çıkan hassas ayar kanıtı kapsamında, evrendeki yaşam koşullarını ifade etmek için insancı ilke (anthropic principle) ileri sürülmüştür. Böylece son dönemdeki bilimsel keşiflerin Tanrı’nın varlığı için ikna edici kanıtlar olduğu iddia edilmiştir. Her ne kadar bilimsel olarak açılamalar eksik olsa da tasarım kanıtının önceki formlarında mantıksal olarak bu tarz iddialar öne sürülmüştür. Fakat burada dikkat edilmesi gereken husus, bu bilimsel gelişmelerden sonraki aşamada yine felsefi açıklamalara başvurulmakta ve Tanrı'nın varlığı bu şekilde kanıtlanmaktadır.

Antropik ilkede, birçok fiziksel ölçü ve değerin neden öyle olduğunun bilimsel açıdan açıllanamadığı ve ateistlerce bu değerlerin tesadüfle meydana geldiğinin kabul edildiği fikrinden yola çıkılarak, amaçlı ve bilinçli bir tasarımcı fikrinin bu durumu açıklamada daha ikna edici olduğu ileri sürülmektedir (Şahin, 2014: 62). Yani Tanrı’nın varlığı, bu bilimsel gelişmelerin sonucunda tasarım kanıtının yeni şekli olarak öne sürülen bir hipotezdir. Temel iddia da karşıt hipotezden daha makul gerekçelere dayandığıdır. Halbuki antropik ilkenin temel iddiasında bir tezat bulunmaktadır. Şöyle ki, antropik ilke olarak ifade edilen bilimsel dengenin hassas ölçüleri, bilimden yola çıkılarak elde edildiyse, daha ilerisinin bilimle elde edilebileceği düşüncesi içi boş bir iddia değildir. Çünkü milyar yıllar alan evrenin şu anki halinin oluşumunda bu değerlerin nasıl meydana geldiği, birçok evrenin var olduğu iddiası ve fiziksel alandaki sabitelerden metafiziksel sonuçlar çıkarılamayacağ düşüncesi gibi mevzular şu an itibariyle çözüme kavuşmuş meseleler değildir. Bu durumun aksine bir noktaya kadar bilime iman eden belli düşünürler, bilimin tıkandığı noktada farklı açıklamalara başvurmaktadırlar. Nitekim yukarıda görüldüğü üzere Flew'ün kendisi de her ne kadar bilimsel açıdan Tanrı’nın varlığına inandığını belirtse de ele aldığı üç kanıtın kendi başına Tanrı'nın varlığını kanıtlamadığını, Swinburne gibi düşünürlerin felsefi yorumlarına dayanarak, önemli olanın bu kanıtlardan elde edilen yapıların anlaşılması olduğunu itiraf etmekteydi.

Dolayısıyla bilimin ilerlemesiyle Tanrı’ya yer kalmayacağını savunanlarla, bilimdeki 
boşlukların Tanrı̉nın varlığına işaret ettiğini, bununla yetinmeyip bilimdeki son gelişmelerin Tanrı'nın varlığının kesin kanıtı olduğunu savunanların unutmaması gereken önemli husus, iman mefhumunun bilgi eksikliği olmadığı, aksine bilgiyle mutlak hakikate erişilemeyeceğinin itiraf edildiği bir tavır olduğudur. Yani bilimsel ilerleyişin imanı diskalifiye edeceği ya da bilimin şimdi olduğu gibi gelecekte de Tanrı’nın varlığını rasyonel anlamda kesinliğe kavuşturacağını savunanlar yanılmaktadırlar. Eğer imanı temellendirmek için öne sürülmüş teist kanıtlar ve karşı tutumu ifade eden ateist kanıtlar, bütün insanlar tarafından kabul edilmiyor ve bazı eleştirilerle her zaman karşı karşıya kalıyorsa, iki tarafın da öne sürdüğü önermelerin bilgide bulunması gereken kesinlikten ve dolayısıyla bağlayıcılıktan uzak olduğu söylenebilir. Bu tablo içerisinde her hangi tutumdaki önermelerin fazla ihtimal oranına sahip olduğu öne sürülse bile, bahsedilen kesinlikten kaynaklanan bağlayıcılığa binaen sadece akli yolla bir sonuca varılması zorlaşacaktır. İşte bu sebeple Tanrı inancı salt akli yolla kanıtlanamaz düşüncesi daha makul görünmektedir. Mesela Flew, Tanrı inancına ulaşırken bunu kesin akli yolla ve bilimsel kanıtlarla yaptığını ileri sürmemelidir. Fakat yeni bilimsel gelişmelerle Tanrının var olma olasılığının var olmama olasılığından daha fazla olduğunu iddia edebilir. Halbuki ilerleyen bilimsel süreçte yeni bilimsel gelişmeler bu ihtimaliyet oranını sürekli değiştirecektir. Belki bilimsel gelişmeler sonucunda Flew'ün pozisyonu karşı mevzide yer almaya göre çok fazla avantaja sahip olacak. Fakat bunun tam tersinin olma ihtimali her zaman var olacaktır. Dolayısıyla imanı ve inancı tamamen bilime dayandırmak ve inancın rasyonelliğini bilimsel kanıtların gücüyle orantılı kılmak kabul edilmesi zor bir durumdur. Bu nedenlerden dolayı Flew’ün ileri sürdügü "rasyonel yolculuk" olayı pek de ikna edici görünmemektedir. Çünkü ateistler de aynı kanıtlardan yola çıkarak kendi tutumlarını rasyonel olarak yorumlayabilir. Bu konuda belli ölçüde bize yardımcı olabilecek husus "Parite Argümanı"dır. Parite argümanı, Tanrı’ya inanmamanın mümkün olduğu gibi inanmanın da imkan dahilinde olduğunu ifade eder. Bu argümanda temel amaç, dini inançlarla dini olmayan her türlü inancın eşit epistemik statüye sahip olduğunu ortaya koymaktır. Bu argüman ateistler tarafından reddedilse de özellikle reformist epistemoloji taraftarları tarafından savunulmaktadır (Mehdiyev, 2008: 19). Dolayısıyla biz bu argümanı ters okuyarak, Flew’ün gerekçelerinden hareket edildiğinde ortaya koyduğu rasyonellik iddiasının, aynı gerekçelerle eşit şekilde ateist tutum için de geçerli olduğunu ileri sürebiliriz.

Flew’ün inançsızlıktan inanca yolculuğu dini bağlamda değerlendirildiğinde ulaşılan sonucun tasdik edilmesi zordur. Yukarıda irdelendiği gibi Flew, bu serüvende kendisinin çok az dahli olmasına rağmen bir çerçeve çizmektedir. Daha doğrusu o, bu yolculuk kendisinin olmasına rağmen, din dili, kötülük, bilimsel gelişme ve felsefi görüşler açısından her daim başkalarının fikirlerine bağlı kalarak pasif duruma düşmüştür. Oysa inanan kişinin bu olguda hiçbir etkisinin olmaması ve tamamen dışsal etkenlerden yola çıkarak imana sahip olması, o kişi açısından varoluşsal bir sorun olacaktır. Çünkü iman olgusunda varoluşsal bir boyut ve doğal teoloji ile elde edilemeyecek kişisel bir yön vardır. Bundan dolayı rasyonel teoloji ile inancın sağlam ve yeteri şekilde gerçekleştiği iddiası dinin ve imanın işlevselliğini hedef alacaktır. Çünkü şayet inanma ve iman etme vakıaları tamamen akli ve bilimsel açıdan mümkünse, Flew'ün durumunda olan birçok kişi, aynı 
kanıtlara bakarak onun iddia ettiği rasyonel ya da bilimsel imana sahip olması gerekir. Ve daha genel anlamda dinin temel inanç önermelerine hatta dinin kendisine gerek kalmaz. Sonuçta Flew'ün bahsettiği tarzda inanç şeklinin ve Tanrı anlayışının, kişisel ve insani alanla iletişimi olan Tanrı anlayışına, vahiy ve peygamberlik müessesesine ve diğer birçok niteliğe sahip din açısından kabul edilmesi imkansızdır.

Habermas ile münazaralarında tartışılan önemli hususlardan biri olan deizm-teizm konusunda Flew'ün içinde bulunduğu karmaşık mevzi, rasyonel teoloji eleştirisinden yola çıkarsak daha net ortaya çıkacaktır. Rasyonel teoloji iki şekilde ifade edilebilir. Bunlardan ilki aşkın teolojidir ki, bunda salt teorik akıl yoluyla kavramdan varlık fikrine ulaşılmaya çalışılır. İkincisi doğal teolojidir ki, bu doğadan, evrenin içinden hareket ederek yaratıcı fikrine ulaşma çabasıdır (Çınar, 2008: 2). Kant, aşkın teolojinin varlık fikrinden hareket ederken, doğal teolojinin evrende var olan parçalardan bütüne yani varlığa doğru hareket ettiğini belirtmektedir. Bu nedenle o, aşkın teolojide Tanrı tasavvurunun deist, doğal teolojininkinin ise teist nitelikte olduğunu belirtir (Kant, 1990: A631/B659). Kant'in rasyonel teoloji eleştirinden yola çıkan Aliye Çınar’a göre doğal teoloji ile aşkın teoloji gerektiğinde karşılıklı olarak birbirlerine dönüşmektedir. Kozmolojik kanıtın ontolojik kanıta geri döndüğü gibi, doğal teoloji de nihai aşamada aşkın teolojiye müracaat eder. Buradan yola çıkarak rasyonel teoloji içerisindeki deist inançla teist inancın birbirinden çok da farklı olmadı̆̆ı sonucu elde edilebilir (Çınar, 2008: 3).

$\mathrm{Bu}$ durum Flew'ün rasyonel tutumundan yola çıkarak ulaştığı deist Tanrı tasavvuru hakkında da geçerlidir. Fakat burada küçük bir ayrım fark edilmelidir. Flew, aslında doğal teoloji yoluyla Tanrı'nın varlığını kabul etmekte, nihai aşamada savunduğu argümanın temellendirmesini felsefi olarak yapmaya çalışmaktadır. Bu duruma bakıldığında doğal teoloji ile hareket eden Flew'ün teist Tanrı inancına sahip olması gerekirken, Kant'in iddiasının aksine deist bir anlayışa sahip olmuştur. Bu noktada Aliye Çınar’n yorumu bizim için çıkış noktasıdır. Deizmle teizmin birbirine geri dönmesi fikri, Flew’ün düşünce seyrindeki durumu özetlemektedir. Sonuçta kötülük meselesindeki çıkmazları da hesaba katan Flew, aşkın teolojinin Tanrı anlayışını kabul ederek deist olduğunu belirtmiştir.

Netice itibariyle rasyonel teolojinin, imanı aklın egemenliği altına alma çabası olduğu söylenebilir. Bu yolla dinin yerine aklın egemenliğindeki bir teoloji inşa edilmiş olacaktır. Böyle bir teolojide iman ve inanç kavramlarının içeriği değişecek, imanın Tanrı’yı bilmekle eşdeğer görüldüğü bir anlayışa ulaşılacaktır. Tabiî ki bu durumun kabul edilmesi imkânsızdır. Çünkü din açısından bakıldığında rasyonel teolojide kabul edilen Tanrı inancının dindekiyle aynı olmadığı aşikârdır. Kant’ın "inanca yer açmak için bilgiyi inkâr ettim” sözü bu bağlamda değerlendirilebilir. Çünkü Tanrı’nın varlığının kanıtlanmayacağını düşünen Kant, bilgi olarak tanımlanan verilerden değil inançtan yola çıkarak numen alanına ulaşılabileceğini belirtmektedir (Kant, 1990: BXXIX). Rasyonel teolojinin Tanrısı, her şeyi bilen ve her şeyi önceden ayarlayan bir varlık olarak, zaman dışı matematik dâhisidir. Evrenin işleyişinden insani durumlara kadar mükemmel bir hassas ayar mekanizmasına sahip olan bu Tanrı anlayışında, ne mucizeye ne duaya vb. unsurlara gerek vardır. Bu Tanrı önceden her şeyi en ince ayrıntısına kadar ayarladığı 
için, evrene ve onun içinde olanlara hiçbir müdahalede bulunmamaktadır (Çınar, 2008: 173-177). Flew'ün düşünce/inanç serüvenindeki tüm eksiklikler ve çelişkiler aslında bu durumun bir özetidir.

\section{SONUÇ}

Flew’ün "kanıtların götürdüğ̈ü yere git” ilkesine uymadığı ve yaşadığı düşünsel serüvenin, kendi subjektif yorumuna göre şekillendiği görülmektedir. Çünkü ateist ve deist dönemlerine bakıldığında Flew'ün Tanrı’nın varlığg konusunda öne sürdüğü argümanların, bir dönem olumsuz diğer dönem olumlu sonuca götürdüğünü varsayabileceğimiz bir durum söz konusu değildir. Ateist olduğu dönemde kötülük meselesi, Tanrı kavramının anlamsızlığı ve teistik kanıtların eleştirisi üzerinden görüşlerini temellendirirken, Tanrı inancına sahip olduğu dönemde daha çok son dönemdeki hassas ayar ve big bang teorilerinden yola çıkarak fikirlerini savunmaktadır. Bu noktada onun önceki dönem düşüncelerini çürüten görüşlere sahip olması ve iki dönem arasındaki gerekçelerde tutarlılığı sağlaması gerekmekteydi. Fakat böyle bir şey söz konusu değildir.

Bununla birlikte özellikle dini ve metafizik alanda, kanıtların her zaman kişiyi kesin bir sonuca götürmeyeceği gerçeği, onun ortaya koyduğu kanıtların kesin kanıt niteliğine sahip olmadığını göstermektedir. Doğa kanunları, hayatın varlığı ve evrenin başlangıcı gibi hususlarda farklı yorumlar yapılabilmektedir. Gelinen noktada Flew'ün bu tarz kanıtlama uğraşıyla elde edilen Tanrı inancının tutarlı ve ikna edici nitelikte olmadığı, kişisel kabullerle sınırlı olduğu kabul edilmelidir. Dolayısıyla modern bilimin ve bu bilim içerisindeki fiziksel, biyolojik vs. bulgular aracılığıyla inşa edilecek Tanrı anlayışının, zaman içerisinde farklı bilimsel bulgularla değişebileceğini ve mevcut dini anlayışla uyumlu bir açıklama olmayacağını görmek zor olmasa gerektir. Nitekim aynı bilimsel gerçekliklerle Tanrı'nın var olmadığına kanaat getirenler bulunmaktadır. Bundan da öte, bilimdeki yeni gelişmelerin Flew'ün öne sürdügü gerekçeler hakkında bugünden çok farklı bilgiler sunabileceği ihtimali, bu temel üzerine inşa edilmiş felsefi inançönermelerinin de objektifliğini sorgulamayı gerektirmektedir. 


\section{KAYNAKÇA}

Aquinas, Thomas (1975). Summa Contra Gentiles. Notre Dame: University of Notre Dame Press.

Ayer, A. J. (1946). Language, Truth and Logic. New York: Dover Pub.

Batak, Kemal (2011). Natüralizm Çıkmazı: Denneet'ten Dawkins'e Yeni Ateizmin Felsefi Temelleri ve Eleştirisi. İstanbul: İz Yayıncılık.

Blackstone, William (1963). The Pproblem of Religious Belief, New York: Prentice-Hall.

Bucaille, Maurice (1988). İnsanın Kökeni Nedir?. çev. Ali Ünal, İstanbul: İnsan Yayınları, 1988.

Craig, W. Lane (1979). The Kalam Cosmological Argument. Oregon: Wipf and Stock Publishers.

Craig, W. Lane (1990). The Teleological Argument and the Anthropic Principle. The Logic of Rational Theism: Exploratory Essays. ed. W. L . Craig and M. McLeod, New York: Edwin Mellen.

Collins, Fancis S. (2007). The Language of God: A Scientist Presents Evidence for Belief. New York: Free Press.

Collins, Fancis S. (2010). Belief: Reading on the Reason for Faith. New York: Harper One.

Çetin, İsmail (2002). İman ve İnkârın Rasyonel Değeri. Uludă̆ Üniversitesi İlahiyat Fakültesi Dergisi, 11/1, 88-102.

Çınar, Aliye (2008). Modern Batı Düşüncesi Ekseninde Rasyonel Teoloji. İstanbul: Düşünce Kitabevi Yay.

Çınar, Aliye (2009). Tanrı Yanılgısı Üzerine: İnanmak ya da İnanmamak, İstanbul: Profil Yay.

Davies, Paul (1983). God and the New Physics. New York: Simon \& Schuster.

Dawkins, Richard (2009). Tanrı Yanılgısı. çev. Tunç Tuncay Bilgin, İstanbul: Kuzey Yay.

Dorman, Emre (2011). Modern Bilim: Tanrı Var. İstanbul: İstanbul Yayınevi.

Evans, C. Stephan (2010). Din Dili Problemi. çev. Ferhat Akdemir, Ondokuz Mayıs Üniversitesi İlahiyat Fakültesi Dergisi, 28, 253-273.

Evans, D. (1972). A Reply to Flew's The Presumption of Atheism. Canadian Journal of Philosophy, 2/1, 47-50.

Flew, Antony (1955). Divine Omnipotence and Human Freedom. New Essays in Philosophical Theology. (ed.) Antony Flew \& Alasdair MacIntyre, London: SCM Press. 144-169.

Flew, Antony (2005). God and Philosophy. New York: Prometheus Books.

Flew, Antony (1955). Theology and Falsification. New Essays in Philosophical Theology. 
(ed.) Antony Flew \& Alasdair MacIntyre, London: SCM Press. 96-99.

Flew, Antony (1969). The Falsification Response. Religious Studies, 5/1, 77-79.

Flew, Antony (1972). The Presumption of Atheism. Canadian Journal of Philosophy, 2/1, 29-46.

Flew, Antony (2007). There is a God: How the World's Most Notorious Atheist Changed His Mind. New York: HarperOne.

Flew, Antony (2014). Yanılmışım Tanrı Varmış. çev. Hasan Kaya ve Zeynep Ertan, İstanbul: Profil Yayıncilik.

Flew, A. ve Habermas, Gary R. (2004). My Pilgrimage from Atheism to Theism: A Discussion between Antony Flew and Gary Habermas. Philosophia Christi, 6/2, 197211.

Habermas, Gary (2007). Antony Flew’s Deism Revisited. Philosophia Christi, 9/2, 431-441.

Hare, R. M. (1955). Theology and Falsification. New Essays in Philosophical Theology, (ed.) Antony Flew \& Alasdair MacIntyre, London: SCM Press. 99-103.

Hick, John (1990). Philosophy of Religion. New Jersey: Prentice Hall İnternational Edition.

Hume, David (1980). Dialogues Concerning Natural Religion. Indianapolis: Hackett.

Jammer, Max (2002). Einstein and Religion. New Jersey: Princeton University Press.

Kant, I. (1990). Critique of Pure Reason. çev. J. Meiklejohn, New York: Prometheus Books.

Kierkegaard, Soren (1962). Philosophical Fragmants. trans. David Swenson, Princeton.

Kütük, Selçuk (2010). Ateizm Yanılgısı. İstanbul: Açılım Kitap.

Lewis, C. S. (1940). The Problem of Pain. London: The Centenary Press.

Mackie, J. L. (1955). Evil and Omnipotence. Mind, New Series, 64/254, 200-212.

Mackie, J. L. (1988). The Miracle of Theism: Argument fort against the Existence of God. Oxford: Clarendon Press.

Mehdiyev, Nebi (2008). Çağdaş Din Felsefesinde Epistemolojik Yaklaşımlar ve Tanrı İnancının Rasyonelliği. İstanbul: İsam Yay.

Mitchell, Basil (1955). Theology and Falsification. New Essays in Philosophical Theology, (ed.) Antony Flew \& Alasdair MacIntyre, London: SCM Press. 103-106.

Nagel, Ernest (1997). Philosophical Concepts of Atheism. Critiques of God: Making the Case against Belief in God, ed. Peter A. Angelles, New York: Prometheus Books.

Ögcem, Ergin (2015). Antony Flew'da Tanrı’ya Dair Paradima Değişikliği. İslam Medeniyetleri Araştırma Dergisi, 1/2, 6-36.

Özcan, Hanifi (1999). Birbirine Zıt İki Epistemolojik Yaklaşım: Temelcilik ve İmancılık. Ankara Üniversitesi İlahiyat Fakültesi Dergisi, XL, 157-176. 
Peterson, Michael vd. (2006). Akıl ve İnanç: Din Felsefesine Giriş. çev. Rahim Acar, İstanbul: Küre Yay.

Planck, Max (1977). Where Is Science Going?. trans. James Murphy, New York: Norton.

Plantinga, Alvin (1975). The Free Will Defence. Readings in Philosophy of Religion: An Analytic Approach, ed. Baruch A. Brody, Prentice-Hall, Inc., Englewood Cliffs, N.J. 186-200.

Polka, Brayton (2006). Philosophy without God? God without Philosophy?: Critical Reflections on Antony Flew's God and Philosophy. The European Legacy, 11/1, 35-46.

Rowe, William (1979). The Problem of Evil and some Varieties of Atheism. American Philosophical Quarterly, 16/4, 335-341.

Scriven, Michael (1997). God and Reason. Critique of God: Making the cae against Belief in God, ed. Peter A. Angeles, New York: Prometheus Books. 95-114.

Smith, Quentin (1992). A Big Bang Cosmological Argument For God's Nonexistence. Faith and Philosophy, 9/2, 217-237.

Stenger, Victor J. (2007). God: The Failed Hypothesis. New York: Prometheus Books.

Swinburne, Richard (2004). Design Defended. Think, 2/6, 13-18.

Swinburne, Richard (1977). The Chorence of Theism. Oxford: Clarendon Press.

Swinburne, Richard (2004). The Existence of God. Oxford: Claredon.

Şahin, Hüseyin (2014). Tanrı’nın Varlığına Dair Modern Delillerden İnsancı İlke ve Hassas Ayar Delili. Artuklu Akademi, 1/2, 57-81.

Tarakçı, Muhammet (2006). St. Thomas Aquinas. İstanbul: İz Yayıncılık.

Tracy, Thomas F. (1984). God, Action and Embodiment. Grand Rapids, MI: Eerdmans.

Uslu, Ferit (2004). Felsefi Açıdan İmanı Temellendirme. Ankara: Ankara Okulu Yayınları.

Varghese, R. Abraham (1998). Great Thinkers on Great Questions. Oxford: Oneworld.

Yıldırım, Ömer Ali (2013). Hudûs Delilinin Gelişimi ve Şehristâni’nin Bu Delile Katkısı. Akademik Araştırmalar Dergisi, 57, 137-156. 